20 Rona RJ, Chinn S. National study for health and growth social and family factors and obesity in primary school children. Ann Hum Biol 1982;9:131-45.

21 Locard E, Mamelle N, Billette A, Miginiac M, Munoz F, Rey S. Risk factors of obesity in a 5 year old population - parenta versus environmental factors. Int $\mathcal{F}$ Obes 1992;16:721-9.

22 Gortmaker SL, Must A, Sobol AM, Peterson K, Colditz GA, Dietz WH. Television viewing as a cause of increasing obesity among children in the United States, 1986-1990. Arch Pediatr Adolesc Med 1996;150:356-62.

23 Dietz W. Factors associated with childhood obesity. Nutrition 1991;7:290-1.

24 Dietz WH, Gortmaker SL. Do we fatten our children at the television set? Obesity and television viewing in children and adolescents. Pediatrics 1985;75:807-12.

25 Rolland-Cachera MF, Deheeger M, Akrout M, Bellisle F. Influence of macronutrients on adiposity development: a follow up study of nutrition and growth from 10 months to 8 years of age. Int 7 Obes 1995;19:573-8.

26 Sorensen TIA, Holst C, Stunkard AJ, Skovgaard LT. Correlations of body mass index of adult adoptees and their biological and adoptive relatives. Int F Obes 1992;16:227-36.

27 Serdula MK, Ivery D, Coates. RJ, Freedman DS, Williamson Serdula MK, Ivery D, Coates RJ, Freedman DS, Williamson
DF, Byers T. Do obese children become obese adults? A DF, Byers T. Do obese children become obese a
review of the literature. Prev Med 1993;22:167-77.

28 Power C, Lake JK, Cole TJ. Measurement and long-term health risks of child/adolescent fatness. Int $\mathcal{F}$ Obes 1997;21 507-26.

29 Power C, Lake JK, Cole TJ. Body mass index and height from childhood to adult life in the 1958 British birth cohort. Am 7 Clin Nutr 1997;66.

30 Butler NR, Bonham DG. Perinatal mortality. Edinburgh: Churchill Livingstone, 1963.

31 Ferri E. Life at 33: the fifth follow-up of the National Child Development Study. London: National Children's Bureau, 1993.
32 Power C, Moynihan C. Social class and changes in weightfor-height between childhood and early adulthood. Int $\mathcal{F}$ Obes 1988;12:445-53.

33 Knight I. The heights and weights of young adults in Great Britain. London: HMSO, 1984.

34 Must A, Dallal GE, Dietz WH. Reference data for obesity: 85th and 95th percentiles of body mass index $\left(\mathrm{wt} / \mathrm{ht}^{2}\right)$ and triceps skinfold thickness. Am f Clin Nutr 1991;53:839-46.

35 Kendall M, Stuart A. The advanced theory of statistics. London: Griffin, 1977:419.

36 Bennett N, Dodd T, Flatley J, Freeth S, Bolling K. The health of our nation: health survey for England 1993. London: Office of Population Censuses and Surveys, 1995:31-43.

37 Gulliford MC, Rona RJ, Chinn S. Trends in body mass index in young adults in England and Scotland from 1973 to 1988. F Epidemiol Community Health 1992;46:187-90.

38 Gortmaker SL, Dietz WH, Sobol AM, Wehler CA. Increasing pediatric obesity in the United States. Am f Dis Child 1987;141:535-40.

39 Shah M, Hannan PJ, Jeffery RW. Secular trend in body mass index in the adult population of three communities from the upper mid-western part of the USA: the Minnesota Heart Health Program. Int F Obes 1991;15:499-503.

40 Sorensen TIA, Price RA. Secular trends in body mass index among Danish young men. Int 7 Obes 1990;14:411-9.

41 Rice T, Bouchard C, Perusse L, Rao DC. Familial clustering of multiple measures of adiposity and fat distribution in the Quebec family study: a trivariate analysis of percent body fat, body mass index, and trunk-to-extremity skinfold ratio. Int $\mathcal{F}$ Obes 1995;19:902-8.

42 Wing RR, Epstein LH, Ossip DJ, LaPorte RE. Reliability and validity of self-report and observers' estimates of relative weight. Addict Behav 1979;4:133-40.

\title{
Birth weight and body fat distribution in adolescent girls
}

\author{
M Barker, S Robinson, C Osmond, D J P Barker
}

MRC Environmental Epidemiology Unit, University of

Southampton,

Southampton General Hospital, Southampton SO16 6YD

M Barker

S Robinson

C Osmond

D J P Barker

Correspondence to: Mary Barker.

\begin{abstract}
Objective-To examine the association between birth weight and body fat distribution in a group of adolescent girls.

Design-A total of 216 white girls who were born in Southampton had their heights, weights, waist and hip circumferences, and skinfold thicknesses measured when they were aged between 14 and 16 years.

Results-The girls who were smallest at birth, but who were fattest at time of measurement were the most centrally obese. In girls whose body mass index was above the median $\left(21 \mathrm{~kg} / \mathrm{m}^{2}\right)$, the subscapular to triceps skinfold ratio rose by $\mathbf{9 \%}$ for every kilogram decrease in birth weight. Among overweight girls, with a body mass index over 25 , the ratio rose by $\mathbf{2 7 \%}$ for every kilogram decrease in birth weight.

Conclusion-In adolescent girls, the tendency to store fat on the trunk rather than the limbs, seems to be programmed by growth in fetal life, and is most evident in those who are overweight.

(Arch Dis Child 1997;77:381-383)
\end{abstract}

Keywords: birth weight; adolescence; body fat distribution
Low weight at birth is associated with the development of non-insulin dependent diabetes and the insulin resistance syndrome in adult life. ${ }^{1}$ Central obesity is a component of this syndrome. This is one of the observations that has led to the hypothesis that non-insulin dependent diabetes and cardiovascular disease are 'programmed' by events in fetal life that lead to persisting changes in the body's structure and metabolic function.

A number of studies suggest that low birth weight is associated with a central pattern of fat distribution. Increased central fat deposition, indicated by a high ratio of subscapular to triceps skinfolds has been found in 7-12 year old children in the USA who were born small, ${ }^{2}$ and also in young adult Mexican-Americans. ${ }^{3}$ Higher waist circumference ${ }^{4}$ and higher waist to hip ratio ${ }^{56}$ have both been associated with low birth weight in adults. These findings suggest that impaired fetal growth leads to increased deposition of fat on the trunk in adult life. A recent case-control study of adolescents in the UK produced findings inconsistent with this hypothesis. ${ }^{7}$ There were no differences in the body fat distribution of low birthweight adolescent girls and boys and normal birthweight adolescent controls. ${ }^{7}$ Differences in study design make it difficult to 
Table 1 Characteristics of the girls $(n=216)$

\begin{tabular}{lll}
\hline & Mean $(S D)$ & Range \\
\hline Age (years) & $15.6(0.4)$ & $14.7-16.6$ \\
Height $(\mathrm{cm})$ & $162.6(6.1)$ & $146.0-179.1$ \\
Waist $(\mathrm{cm})$ & $68.9(6.4)$ & $57.0-91.9$ \\
Hip $(\mathrm{cm})$ & $95.3(6.4)$ & $77.0-118.2$ \\
Waist to hip ratio & $0.72(0.04)$ & $0.61-0.86$ \\
Body mass index $\left(\mathrm{kg} / \mathrm{m}^{2}\right)$ & $21.5(2.8)$ & $15.7-30.0$ \\
Triceps skinfold $(\mathrm{mm})$ & $15.7(4.8)$ & $5.8-28.0$ \\
Subscapular skinfold $(\mathrm{mm})$ & $12.2(5.0)$ & $5.9-39.3$ \\
Subscapular to triceps ratio & $0.78(0.19)$ & $0.46-1.60$ \\
Birth weight (g) & $3295(509)$ & $1220-5180$ \\
Gestation at birth (days) & $282(13)$ & $225-309$ \\
\hline
\end{tabular}

compare the results of this study with others. We have therefore examined the association between birth weight and body fat distribution in a group of adolescent girls with a range of birth weights. The girls were at school in the south of England and took part in a nutrition survey.

\section{Subjects and methods}

A total of 348 white girls were recruited from five schools in the Southampton area to take part in a study of diet and body composition carried out between September 1995 and July 1996. The schools were chosen to give a mix of social classes. Girls between the ages of 14 and 16 were invited to take part; $83 \%$ of them agreed to do so. The study was explained to parents and girls, and each girl gave her written consent. Ethical approval was given by the Southampton and South-West Hampshire local research ethics committee.

Each girl completed a questionnaire asking where and when she was born, about her smoking habits and household composition, and about the occupation of her head of household. Maternity records of the mothers were located for 216 of the 242 singleton girls born locally (89\%). Birth weight and gestational age at birth were abstracted. Current social class of the girls was assigned according to the occupation of the head of household. The occupations of head of household for 19 of the 216 girls could not be classified or were unknown.

Measurements were taken of each girl's height and weight. Height was measured with a Harpenden portable stadiometer to the nearest $0.1 \mathrm{~cm}$, and weight with a Seca scale to the nearest $0.1 \mathrm{~kg}$. Waist and hip circumferences were measured with a steel tape to the nearest $0.1 \mathrm{~cm}$. Skinfold thicknesses were measured to $0.1 \mathrm{~mm}$ on the non-dominant side of the body at the subscapular and triceps sites, and in the manner described by Durnin and Wormersley, ${ }^{8}$ using Harpenden callipers. Each skinfold measurement was taken in triplicate. Before the study began, field workers were trained and

Table 2 Mean (geometric) subscapular to triceps ratio by birth weight in girls above and below the median body mass index (numbers of girls in parantheses)

\begin{tabular}{|c|c|c|c|}
\hline \multirow[b]{2}{*}{ Birth weight $(g)$} & \multicolumn{2}{|c|}{ Body mass index $\left(\mathrm{kg} / \mathrm{m}^{2}\right)$} & \multirow[b]{2}{*}{ Total } \\
\hline & $\leqslant 21$ & $>21$ & \\
\hline$\leqslant 3000$ & 0.78 & $0.80(24)$ & $0.79(55)$ \\
\hline $3001-3500$ & $0.73(44)$ & $0.78(49)$ & $0.76(93)$ \\
\hline$>3500$ & 0.75 (33) & $0.74(35)$ & $0.75(68)$ \\
\hline Total & $0.75(108)$ & $0.78(108)$ & $0.76(216)$ \\
\hline
\end{tabular}

the measurement procedures standardised. Standardisation and retraining were carried out at three monthly intervals throughout the study.

The mean of the three skinfold measurements taken at each site was calculated and used in the analysis. The subscapular to triceps skinfold ratio was calculated as an index of truncal to peripheral adiposity after Haffner et $a l .{ }^{9}$ The distributions of the skinfold values were skewed, and were therefore log transformed before analysis. Variables relating to current and early life factors were entered into a multiple regression analysis. Social class was treated as a dichotomous variable, manual versus non-manual households, in tests comparing means, and as a continuous variable in regression analyses.

\section{Results}

Age and unadjusted anthropometric details for the 216 girls are given in table 1 . There were 98 girls from manual (IIIm, IV, and V) households, and 99 from non-manual (I, II, and IIInm) households. Girls from manual households tended to be shorter and heavier than girls from non-manual households.

As expected, the triceps and subscapular skinfolds, the subscapular to triceps skinfold ratio and the waist to hip ratio were all positively related to body mass index, though the association with skinfold ratio was not statistically significant. Body mass index and skinfold thicknesses fell with increasing age, and values were therefore adjusted to 15.0 years in all subsequent analyses.

Birth weight was positively associated with body mass index $(p=0.08)$. After adjusting for body mass index, birth weight was negatively associated with both subscapular skinfold thickness $(p=0.02)$, and the subscapular to triceps ratio $(p=0.05)$. It was not associated with triceps skinfold thickness. Subscapular skinfold thickness increased by $7 \%$ for every kilogram decrease in birth weight $(95 \%$ confidence interval (CI) $1 \%$ to $13 \%$ ), while the ratio increased by $6 \%$ per kilogram decrease in birth weight $(95 \%$ CI $0 \%$ to $12 \%)$. These associations were independent of the girl's social class.

Table 2 shows the skinfold ratio by birth weight among girls below and above the median body mass $\left(21 \mathrm{~kg} / \mathrm{m}^{2}\right)$. The association between birth weight and the skinfold ratio was strong in girls with body mass indices above the median, among whom there was an $9 \%$ increase in the skinfold ratio for every kilogram decrease in birth weight $(\mathrm{p}=0.02 ; 95 \%$ CI $1 \%$ to $16 \%$ ). At body mass indices over 25 , conventionally described as 'overweight', this pattern was even more marked. The skinfold ratio increased by $27 \%$ for every kilogram decrease in birth weight $(\mathrm{p}=0.03,95 \%$ CI $3 \%$ to $56 \%$ ). The three girls who had body mass indices over 25 and birth weights below $3 \mathrm{~kg}$ had a mean skinfold ratio of 1.25 .

There were no associations between gestational age at birth and the girls' anthropometry, even after allowing for body mass index. Inclusion of gestational age in the 
regression weakened, but did not change, the effect of birth weight on subscapular skinfold thicknesses or on the ratio of subscapular to triceps skinfolds.

\section{Discussion}

We have studied birth weight and body fat distribution in girls aged between 14 and 16 years. Recent national statistics indicate that the mean height and weight of girls in our sample corresponds with that for girls of this age in southern England. ${ }^{10}$ In line with national trends, girls from manual households had a higher mean body mass index. The distribution of birth weight in the group was the same as that for all UK births at the time these girls were born. ${ }^{11}$

Birth weight was positively related to body mass index. After allowing for this, we found that low birth weight was associated with a tendency to store fat centrally, measured by an increased subscapular skinfold thickness and a higher ratio of subscapular to triceps skinfold thicknesses. These relationships were independent of the girls' gestational age at birth and current social class. They confirm findings from two previous studies of children and young adults. ${ }^{23}$ The girls in our study were at varying stages of the adolescent growth spurt, when body fat distribution changes. This might weaken associations between birth weight and central fat deposition. In our study, low birth weight was not associated with an increased waist to hip ratio. Subscapular to triceps skinfold ratio and waist to hip ratio reflect different aspects of body fat distribution, and the association between low birth weight and high waist to hip ratio has only been described in older adults. ${ }^{4-6}$

Central fat deposition is associated with insulin resistance and an increased risk of noninsulin dependent diabetes in women, independently of overall level of body fatness. ${ }^{912} 13$ Our data show that teenage girls in Britain who were small at birth but who are fatter at age 14 to 16 are already depositing fat centrally. Adolescence has been identified as a critical period for the development of obesity. ${ }^{14} \mathrm{~A}$ higher than average body mass in adolescence may therefore entrain a tendency to deposit fat centrally, which is initiated by undernutrition in fetal life. Because of its association with insulin resistance, the development of central obesity in young women may have implications not only for their long term health, but for the intrauterine development of their offspring. It may be important for girls who were small at birth to avoid becoming overweight.

We are grateful to all the girls who took part in the study, and to the schools for their cooperation. Fieldwork was carried out by Wendy Arnold, Valerie Davill, Lyn Greenaway, Julia Hammond, Amanda Jones, Ria Skelton, and Christine Weston. The study was funded by the Dunhill Medical Trust.

1 Barker DJP. Fetal origins of coronary heart disease. BMF 1995;311:171-4

2 Malina RM, Katzmarzyk PT, Beunen G. Birth weight and its relationship to size attained and relative fat distribution at 7 to 12 years of age. Obes Res 1996;4:385-90.

3 Valdez R, Athens MA, Thompson GH, Bradshaw BS, Stern MP. Birthweight and adult health outcomes in a biethnic population in the USA. Diabetologia 1994;37:624-31.

4 Han TS, McNeill G, Campbell DM. The relationship between women's birth weight and their current intraabdominal fat-mass. Proceedings of the Nutrition Society 1995;54:182A

5 Law CM, Barker DJP, Osmond C, Fall CHD, Simmonds SJ. Early growth and abdominal fatness in adult life. $\mathcal{f}$ Epidemiol Community Health 1992;46:184-6.

6 Fall CHD, Osmond C, Barker DJP, et al. Fetal and infant growth and cardiovascular risk factors in women. $B M \mathcal{F}$ 1995;310:428-32

7 Matthes JWA, Lewis PA, Davies DP, Bethel JA. Body size and subcutaneous fat patterning in adolescence. Arch Dis Child 1996;75:521-3.

8 Durnin JVGA, Wormersley J. Body fat assessed from total body density and its estimation from skinfold thickness: measurements on 481 men and women aged from 16 to 72 years. Br F Nutr 1974;32:77-97.

9 Haffner SM, Stern MP, Hazuda HP, Pugh J, Patterson JK. Do upper-body and centralized adiposity measure different aspects of regional body-fat distribution? Relationship to non-insulin-dependent diabetes mellitus, lipids, and liponon-insulin-dependent diabetes
proteins. Diabetes 1987;36:43-51.

10 Colhoun H, Lampe F, Dong W. Obesity. In: Colhoun H, Prescott-Clarke P, eds. Health survey for England 1994: findings. London: HMSO, 1996: 236-53.

11 Macfarlane A, Mugford B. Birth counts. London: HMSO, 1980.

12 Bjorntorp P. Visceral obesity: a 'civilisation syndrome'. Obes Res 1993;1:206-22.

13 Higgins M, Kannel W, Garrison R, Pinsky J, Stokes J. Hazards of obesity - the Framingham experience. Acta Med Scand 1988;suppl 723:23-36.

14 Dietz WH. Early influences on body weight regulation. In: Bouchard C, Bray GA, eds. Regulation of body weight. Chichester: John Wiley and Sons, 1996. 